\title{
Possible impacts of climate change on debris-flow activity in the Swiss Alps
}

\author{
Markus Stoffel • Thomas Mendlik • Michelle Schneuwly-Bollschweiler • \\ Andreas Gobiet
}

Received: 6 June 2013 / Accepted: 21 October 2013 / Published online: 10 November 2013

(C) Springer Science+Business Media Dordrecht 2013

\begin{abstract}
This study uses a long dataset of past debris flows from eight high-elevation catchments in the Swiss Alps for which triggering conditions since AD 1864 have been reconstructed. The torrents under investigation have unlimited sediment supply and the triggering of debris flows is thus mainly controlled by climatic factors. Based on point-based downscaled climate scenarios for meteorological stations located next to the catchments and for the periods 2001-2050 and 2051-2100, we study the evolution of temperature and rainfall above specific thresholds $(10,20$, 30,40 and $50 \mathrm{~mm}$ ) and durations (1,2 or 3 days). We conclude that the drier conditions in future summers and the wetting of springs, falls and early winters are likely to have significant impacts on the behavior of debris flows. Based on the current understanding of debris-flow systems and their reaction to rainfall inputs, one might expect only slight changes in the overall frequency of events by the mid- $21^{\text {st }}$ century, but possibly an increase in the overall magnitude of debris flows due to larger volumes of sediment delivered to the channels and an increase in extreme precipitation events. In the second half of the $21^{\text {st }}$ century, the number of days with conditions favorable for the release of debris flows will likely decrease, especially in summer. The anticipated increase of rainfall during the shoulder seasons (March, April, November, December) is not expected to compensate for the decrease in future heavy summer rainfall over 2 or 3 days.
\end{abstract}

\section{Introduction}

Projected changes in mean and extreme temperatures and precipitations are likely to influence the temporal frequency and magnitude of mass movements in mountain environments (e.g.,

Electronic supplementary material The online version of this article (doi:10.1007/s10584-013-0993-z) contains supplementary material, which is available to authorized users.

M. Stoffel $(\bowtie) \cdot$ M. Schneuwly-Bollschweiler

University of Geneva, Institute for Environmental Sciences, Climatic Change and Climate Impacts,

7 route de Drize, $\mathrm{CH}-1227$ Carouge, Switzerland

e-mail: markus.stoffel@dendrolab.ch

M. Stoffel • M. Schneuwly-Bollschweiler

University of Bern, Institute of Geological Sciences, dendrolab.ch,

Baltzerstrasse 1+3, CH-3012 Bern, Switzerland

T. Mendlik • A. Gobiet

University of Graz, Wegener Center for Climate and Global Change,

Brandhofgasse 5, A-8010 Graz, Austria 
IPCC 2012; 2013; Gobiet et al. 2013). This is especially true for debris flows where changes in rainfall intensity and duration, in combination with higher temperatures, are thought to lead to increased frequency, provided that sediment is not limited and that the occurrence of events is driven above all by water input above a certain hydroclimatic threshold (e.g., Borga et al. in press). A warmer climate is also likely to result in higher $0{ }^{\circ} \mathrm{C}$ isotherms, thus allowing for more precipitation to fall as rain, thereby increasing the area contributing effectively to runoff (Stoffel and Beniston 2006). In addition, warmer air temperatures are also likely to promote the degradation of permafrost even further over the next few decades (Salzmann et al. 2007), which in turn may liberate additional sources of unconsolidated material (Harris et al. 2009). Conversely, increasing air temperatures will allow vegetation to grow at higher altitudes and to stabilize loose material (Baroni et al. 2007), provided that ground is sufficiently stable and that slope gradients are not too steep. Such conditions are not, however, very common in highmountain source areas of debris flows. There is a common understanding that mean and maximum air temperatures have increased considerably and that the global average temperature of the past few decades was warmer than any comparable period during (at least) the last 200 years (PAGES 2k consortium 2013). With the ongoing climate change, mean and extreme temperatures are expected to continue to rise considerably over the next decades (IPCC 2013).

Changes in precipitation, in particular heavy precipitation events, have been demonstrated to affect the occurrence of debris flows as well. Several studies have documented a significant increase in high-intensity precipitation over Europe (Lendernik and Meijgarrd 2008). In the Swiss Alps, solid and liquid precipitation totals have increased in fall and winter (Widmann and Schär 1997; Schmidli et al. 2002; Schmidli and Frei 2005). Projections for future precipitation are consistent with past changes, but future changes tend to be less uniform and more hidden in natural variability and model errors as compared to temperature projections (Meehl et al. 2007). As a result of the thermodynamic effect described by the Clausius-Clapeyron relation, a warming atmosphere will also translate into higher air moisture content, which in turn may increase the potential for increased frequency and intensity of heavy precipitation events over the Alps (Pall et al. 2007). Several studies indicate that future heavy precipitation might tends to increase in fall and winter whereas models portray a less consistent picture for future summers (Beniston et al. 2007; Kysely and Beranova 2009; Schmidli and Frei 2005; Schmidli et al. 2007; Rajczak et al. 2013; Christensen et al. 2007; Orlowsky and Seneviratne 2012).

The impact of climatic changes on permafrost stability (Kääb 2008) or glacier wasting (Chiarle et al. 2007) and the associated occurrence of debris flows have been addressed in a series of studies, mostly focusing on the European Alps. Keiler et al. (2010), for instance, assumed that climatic changes and related glacier and permafrost melting could lead to widespread surface destabilization and an increase in the frequency and magnitude of geomorphic hazards. Sattler et al. (2010) compared zones of marginal permafrost with recent (post1983) initiation zones of debris flows, and conclude that no links exist between atmospheric warming, permafrost degradation and debris flows occurrence in South Tyrol. In the Italian Dolomites, Floris et al. (2010) observed an increase in high-intensity, short-duration rainfalls since 1990 and suggested that such local changes could lead to more rainfall events which can potentially trigger debris flows. Similar results were reported for non-permafrost sites in the French Alps, where Jomelli et al. (2007; 2009) predict a decrease in debris-flow frequency.

In the Swiss Alps, Stoffel et al. (2008) speculated that the frequency of periglacial debris flows could decrease in the Valais Alps (Switzerland) as a result of drier summers and a generally smaller numbers of intense summer precipitation. At the same time, unless slopes are stabilized by vegetation, debris-flow volumes could be on the rise as a result of increased availability of loose sediment, longer return periods and presumably fewer, but more intense rainfalls in summer (Stoffel 2010). 
Uncertainty and diverging conclusions on future debris-flow activity primarily stem from (i) the error margins inherent in scenario-driven global climate projections, (ii) lacking spatial resolution of downscaled climate projections (Crozier 2010) and limited information on past process behavior in the catchments under investigation (Bollschweiler and Stoffel 2010).

This study uses a very comprehensive dataset of debris flows from eight high-elevation catchments in the Swiss Alps for which hydroclimatic conditions leading to the release of events were reconstructed for the period 1864-2010 (Schneuwly-Bollschweiler and Stoffel 2012). The eight torrents have unlimited sediment supply and the triggering of debris flows is therefore mainly controlled by climatic factors. Based on the knowledge on past events, we (i) develop point-based downscaled climate scenarios for meteorological stations located next to the catchments and for the periods 2001-2050 and 2051-2100. The evolution of (ii) rainfalls with specific thresholds (10, 20, 30, 40 and $50 \mathrm{~mm}$ ) and specific durations (1, 2 or 3 days) is investigated and (iii) correlated with the percentage of rainfalls that has triggered debris flows in the past.

\section{Past debris-flow occurrences in the study region}

The region chosen for analysis is the Zermatt Valley (central coordinates $46^{\circ} 10^{\prime} \mathrm{N} . / 47^{\circ} 7^{\prime} \mathrm{E}$.; Fig. 1), a high-elevation, north-south oriented valley in the Swiss Alps. The valley is characterized by a steep relief; the highest peak is 4,634 $\mathrm{m}$ asl (Dufourspitze), the valley floor has elevations ranging from ca. 1,100 in the North to $1,600 \mathrm{~m}$ asl in the South. Eight debris-flow torrents are investigated in this study. They all have a western exposure, very similar geomorphic conditions and source areas of debris flows in permafrost (BAFU 2006). Extensive till, scree slopes and rock glaciers represent the principal and unlimited sediment sources for debris flows which are commonly triggered at elevations between 2,000 and $3,000 \mathrm{~m}$ asl Slope angles in the initiation zones range from 27 to $41^{\circ}\left(\right.$ mean $\left.33^{\circ}\right)$ and debris-flow channels are $22-33^{\circ}$ (mean $28^{\circ}$ ). Annual precipitation is $589 \mathrm{~mm}$ in Grächen and $639 \mathrm{~mm}$ in Zermatt (mean for the climate normal 1981-2010). Despite the proximity of the two stations, differences in annual precipitation totals and rainy days are considerable and reflective of the immediate proximity of Zermatt to the main divide. Mean annual air temperatures were 6.0 and $4.2{ }^{\circ} \mathrm{C}$ at Grächen and Zermatt, respectively (MeteoSwiss 2013). January through April are the driest months with a monthly mean of 30-40 mm precipitation (snow or rain), whereas October is the wettest month with $63( \pm 52) \mathrm{mm}$ of precipitation. As a consequence of the difference in elevation between the meteorological stations of Grächen $(1,550 \mathrm{~m}$ asl) and Zermatt $(1,638 \mathrm{~m}$ asl), a $5^{\circ} \mathrm{C}$ threshold has found to be useful for a distinction of liquid and solid precipitation in the source areas of debris flows mostly located between 2,400 and 2,700 m asl.

The database on past debris flows in the eight catchments is illustrated in Supplementary Fig. S1 and has been constructed with archival and dendrogeomorphic records of past debris flows (Bollschweiler et al. 2008a; Stoffel et al. 2008). It contains information on 417 debris flows which occurred in 226 different years between AD 1600 and 2008 (Bollschweiler and Stoffel 2010). The intra-seasonal timing of debris flows between 1864 and 2008 was reconstructed using the position of injuries and/or tangential rows of traumatic resin ducts (Bollschweiler et al. 2008b; Stoffel et al. 2005a; Stoffel 2008) in the growth series of tree rings.

As a result of cooler mean air temperatures, debris-flow activity was mostly restricted to June through September during the $19^{\text {th }}$ century, but tends to start in May and to cease in October, especially since the start of pronounced warming in the 1980s (Schneuwly-Bollschweiler and Stoffel 2012). Coupling of debris-flow with daily rainfall data shows that events can be triggered with precipitation totals $>20 \mathrm{~mm}$ and that minimum rainfall thresholds are lower early in the season (MJ) than late in the season (SO). This is likely due to a thin active layer of the permafrost body early in MJ which limits the depth to an impermeable layer, meaning that less water will be needed to 


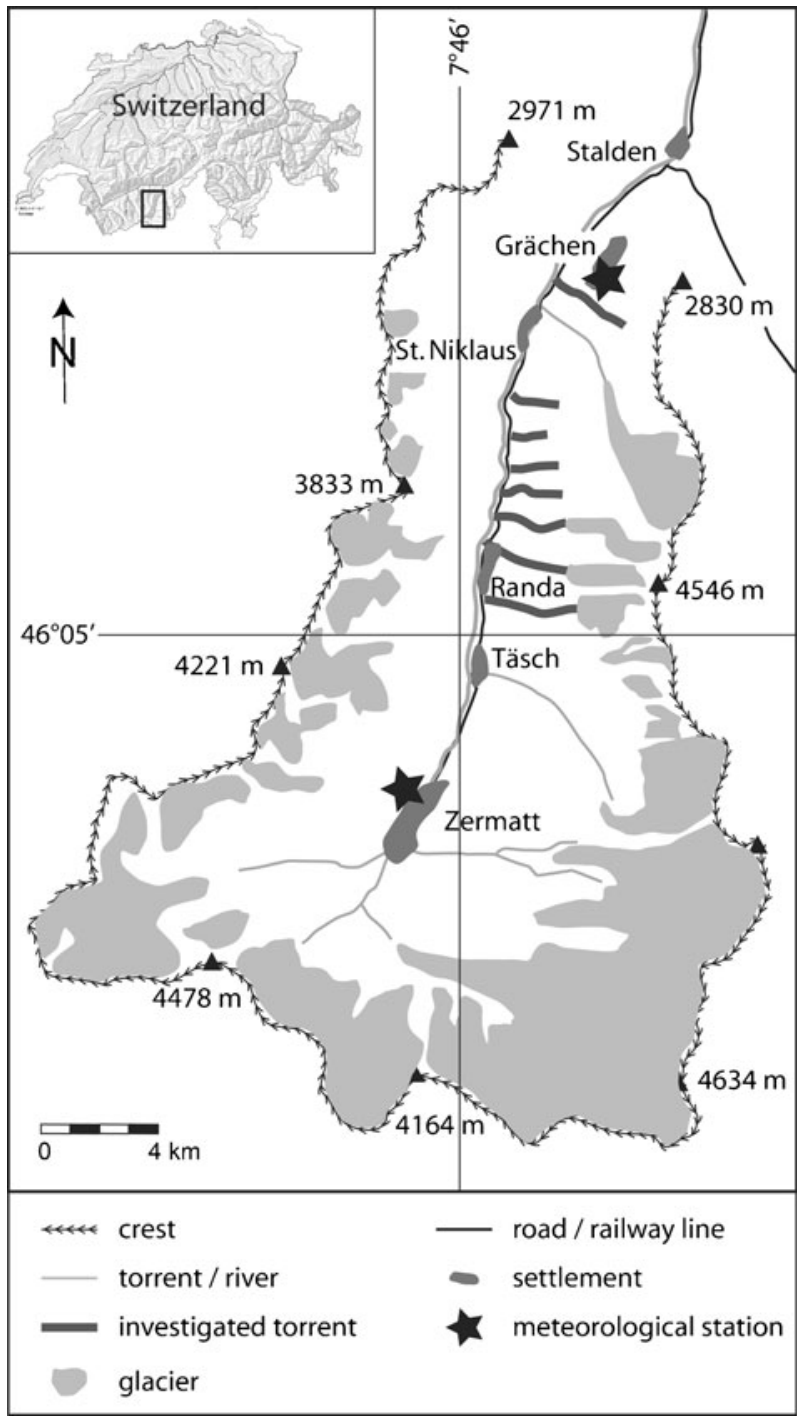

Fig. 1 Study region in the Swiss Alps with torrents investigated and meteorological records used

achieve positive pore water pressure (Lugon and Stoffel 2010). As a consequence, debris flows are mostly triggered by short-duration, high-intensity rainfalls early in the season, whereas persistent advective rainfalls become more important in late summer and fall (Stoffel et al. 2011). Table 1 provides the total and effective number of rainfalls over a specific threshold (10, 20, 30, 40, and $50 \mathrm{~mm}$ in 1,2 , or $3 \mathrm{~d}$ ), with the latter indicating the relative number of rainfalls which triggered a debris flow. Results are provided for the entire period for which data is available (1864-2008) and for the period 1951-2000, i.e. the period used here for the calibration of downscaled RCM data. During the second half of the 20th century, rainfall totals of 20,30, and $40 \mathrm{~mm} \mathrm{~d}^{-1}$ have had a triggering frequency of $32 \%, 35 \%$, and $45 \%$, respectively, in at least one of the catchments. Thresholds beyond $40 \mathrm{~mm} \mathrm{~d}^{-1}$ do not improve the percentage of effective rainfalls. Values for the 2and 3-d rainfalls show similar tendencies, but slightly lower triggering frequencies. 


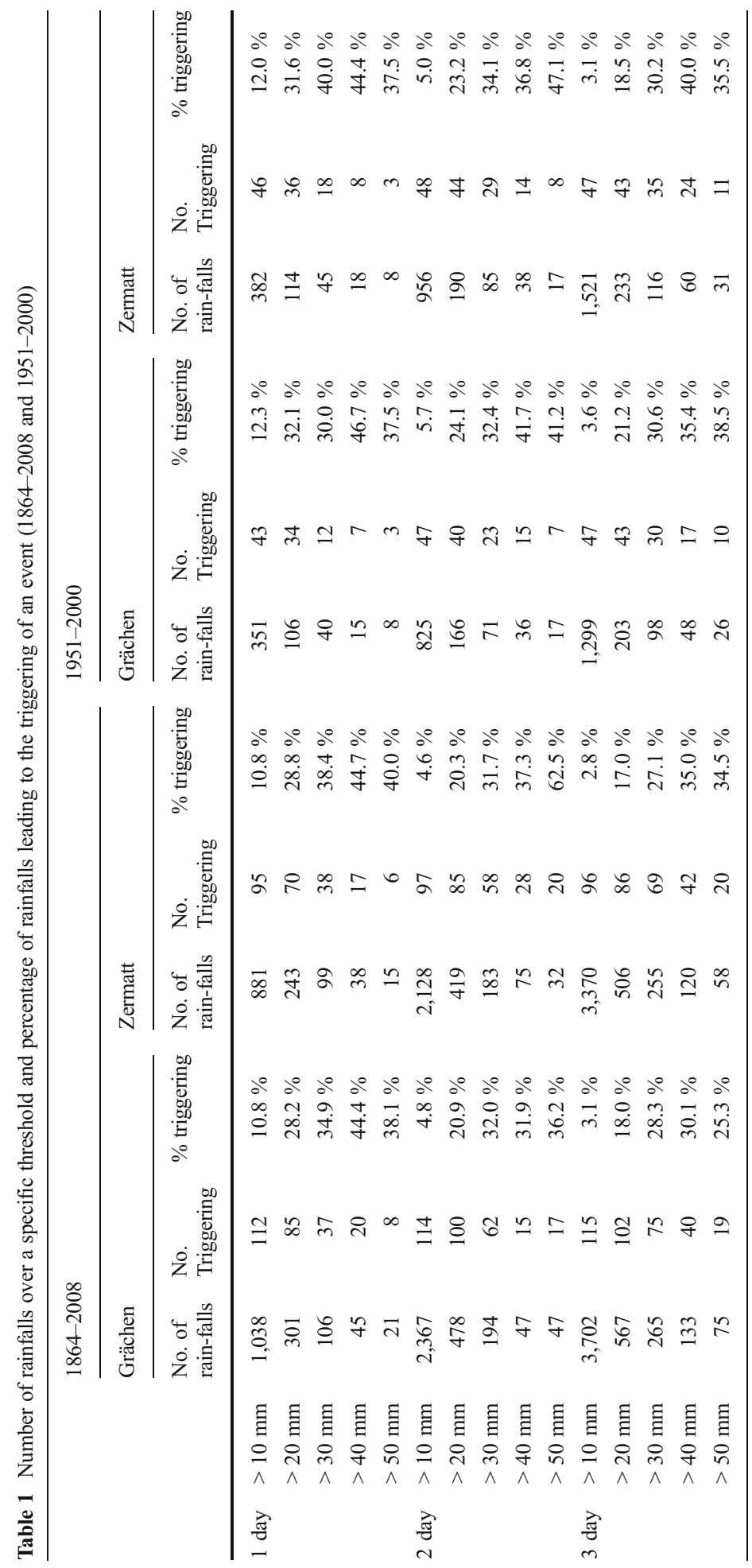




\section{Climate data and methods}

The meteorological stations are Grächen $\left(46^{\circ} 11^{\prime} \mathrm{N}, 7^{\circ} 49^{\prime} \mathrm{E} ; 1,619 \mathrm{~m}\right.$ asl) and Zermatt $\left(46^{\circ} 01^{\prime}\right.$ $\mathrm{N}, 7^{\circ} 45^{\prime} \mathrm{E}$; 1,638 m asl), illustrated in Fig. 1. Grächen has been operational since 1863 (MeteoSwiss 2013). The station has a continuous daily precipitation and temperature record from December 1863 to December 1886 and from January 1891 to the current day. Daily data was homogenized since the station was moved in 1998. The Zermatt station has been operational since January 1900 and has daily precipitation for the entire period, and temperature data from 1959-1971 and 1981 to the current day.

Estimation of future debris-flow frequency in the study region is based on changes in future climatic conditions in the area. Analysis draws on the conclusions of regional climate models (RCM, 25×25 km grid) from the EU-FP6 ENSEMBLES project (www.ensembles-eu.org) and using the IPCC A1B greenhouse gas emission scenario. The choice of emission scenarios has only limited impacts on climate change over Europe during the first half of the 21st century (Prein et al. 2011). For the late-21st century, however, the A1B scenario differs markedly from the other two major scenarios from the IPCC AR4 report, namely B1 and A2 (Solomon et al. 2007) with a temperature evolution warmer than B1 but cooler than A2. The entire set of 22 (15) simulations has been used for the period 2001-2050 (2051-2100) to fully assess the range of climate model uncertainty.

As RCMs are known to suffer from systematic errors, an empirical-statistical error correction and downscaling method (quantile mapping or QM); e.g., Dobler and Ahrens 2008; Piani et al. 2010; Themeß1 et al. 2011) was applied to adjust and refine regional model results towards the local-scale observations, using the daily observational data from Zermatt and Grächen. The error correction in this study was done in the framework of the EU-FP7 project ACQWA (http:// www.acqwa.ch/) and is based on an empirical implementation of QM as described by Themeß1 et al.(2012) and Wilcke et al. (2013) and already applied in other climate change impact studies (Heinrich and Gobiet, 2012). QM adapts modeled time series by adjusting the modeled empirical cumulative frequency distributions of daily temperature and precipitation to the observed frequency distribution of the calibration period 1961-2009. This means that over this entire period the error-corrected model data have the same distribution as the observed data, but the chronological sequence of weather patterns originates from the RCM. In order to allow extreme temperatures or precipitation sums beyond the calibration range, we extrapolate the correction term of the most extreme value of the RCM from the calibration period.

\section{Results}

Temperature and precipitation changes have been analyzed for six periods of two months each (i.e. January-February (JF), March-April (MA), May-June (MJ), July-August (JA), September-October (SO), and November-December (ND)) for the reference period (1951$2000)$ as well as for the mid (2001-2050; 22 downscaled RCMs) and the late (2051-2100; 15 downscaled RCMs) $21^{\text {st }}$ century. In terms of debris flows, the most interesting periods are MJ, $\mathrm{JA}$, and $\mathrm{SO}$, and in particular the evolution of precipitation very early (April, May) and late (October) in the debris-flow season.

\subsection{Temperature increase and extension of the debris-flow season}

The expected temperature change is presented in Fig. 2 for the meteorological station at Grächen. The temperature signal is consistently positive in all models, indicating a strong 

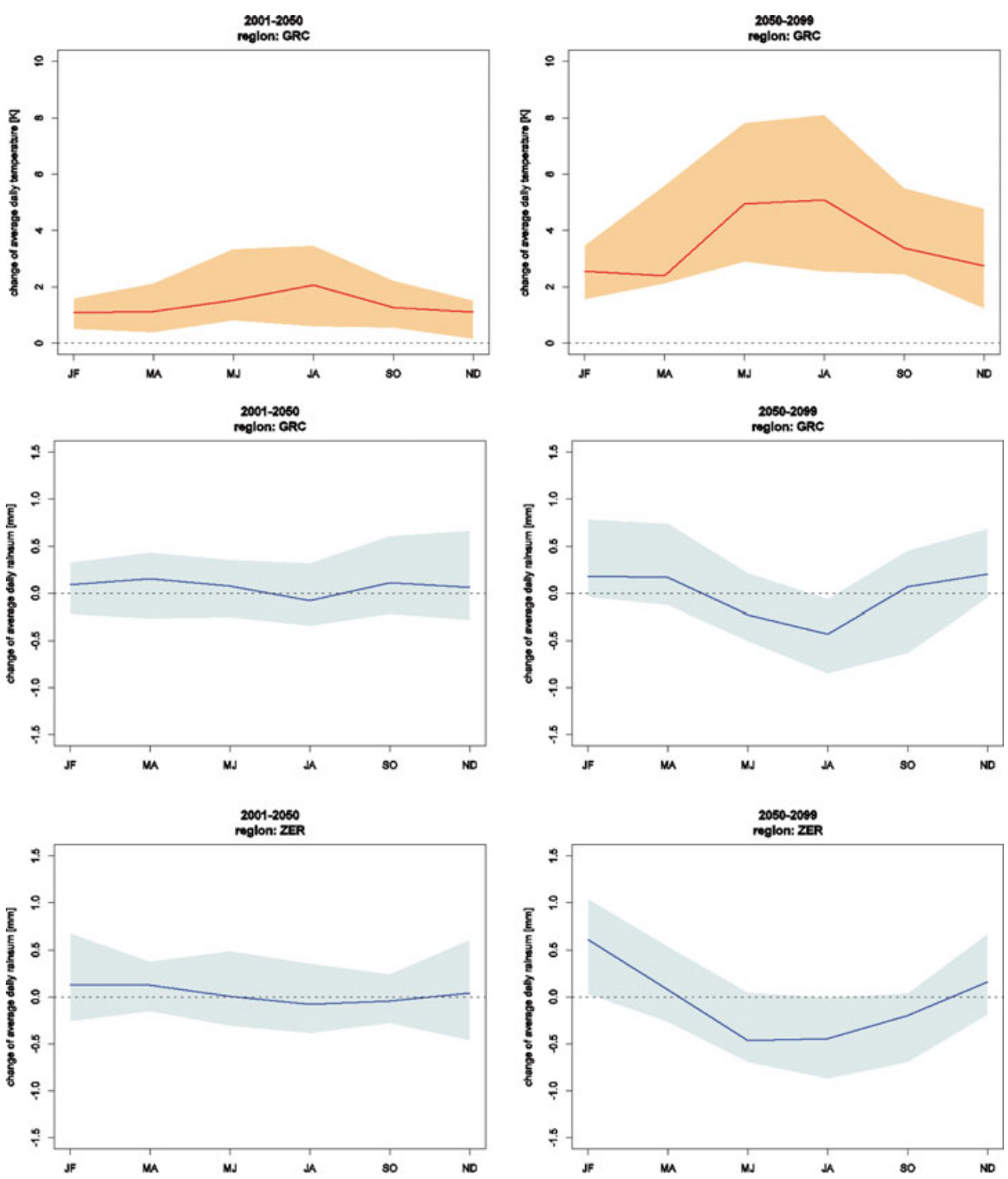

Fig. 2 (top) Temperature change at the meteorological station of Grächen by (a) 2001-2050 and (b) 2050-2099 with respect to the 1951-2000 reference period. Data is derived from 22 (2001-2050) and 15 (2050-2099) bias corrected RCMs. (bottom) Precipitation sum changes at the meteorological stations of Grächen and Zermatt by (a) 2001-2050 and (b) 2050-2099 with respect to the 1951-2000 reference period. Data is derived from 22 (2001-2050) and 15 (2050-2099) bias corrected RCMs. The red line shows the median model, the shaded area depicts the 5 th -95 th percentile range

increase of air temperatures for 2001-2050 and 2050-2099 as compared to the reference period (1951-2000). Highest warming is projected for MJ (median increase of $1.5 \mathrm{~K}$ and $4.9 \mathrm{~K}$ until 2050 and 2100 , respectively) and JA (2.1 and $5.1 \mathrm{~K})$, but model uncertainty is also largest for these months for which the highest projections exceed $+8 \mathrm{~K}$ (Fig. 2). Projected SO temperatures exhibit a median warming of 1.3 and $3.4 \mathrm{~K}$ by 2050 and 2100 , respectively (Fig. 3).

During the control period, the release of debris flows has not been limited by air temperatures, but low temperatures and associated snowfalls have been limiting debris-flow activity 
Grächen precip > 30 mm (2001-50)

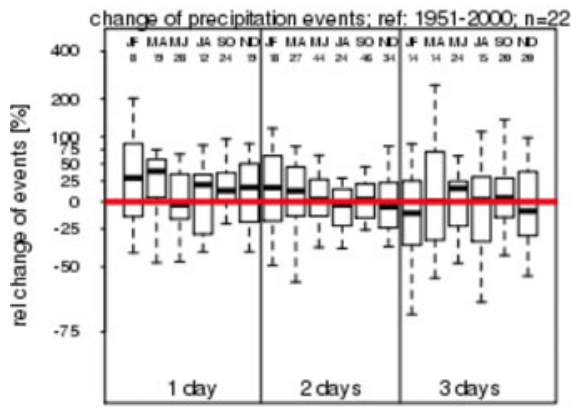

Grächen precip > 50 mm (2001-50)

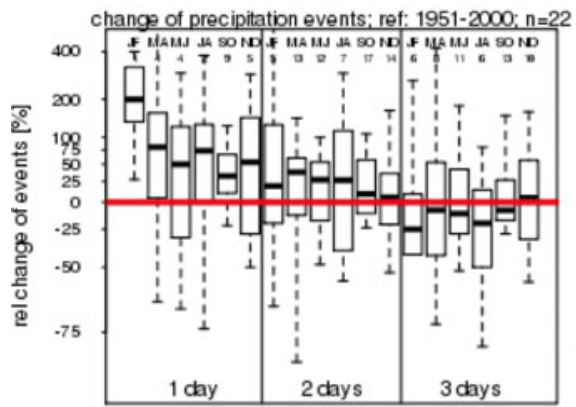

Zermatt precip > 30 mm (2001-50)

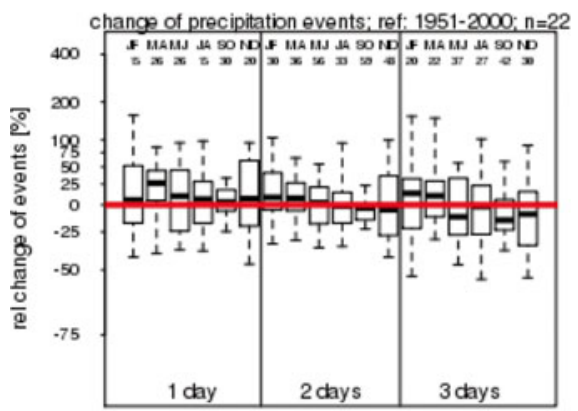

Zermatt precip > 50 mm (2001-50)

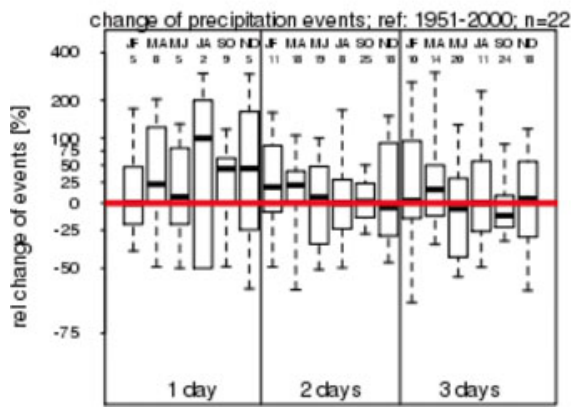

Grächen precip > 30 mm (2050-99)

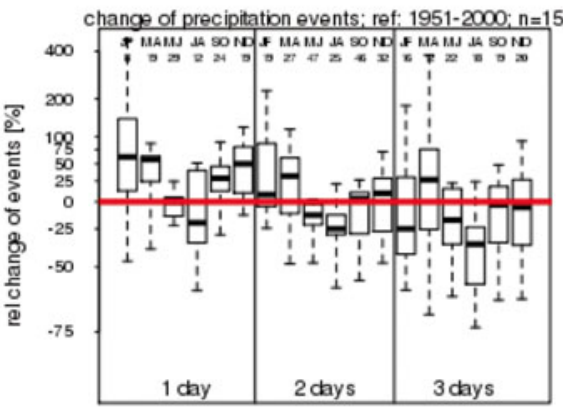

Grächen precip > 50 mm (2050-99)

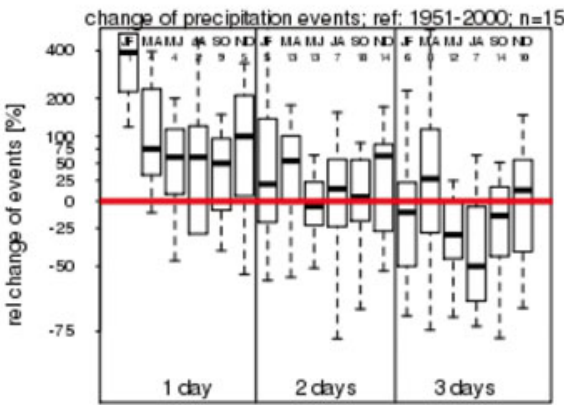

Zermatt precip > 30 mm (2050-99)

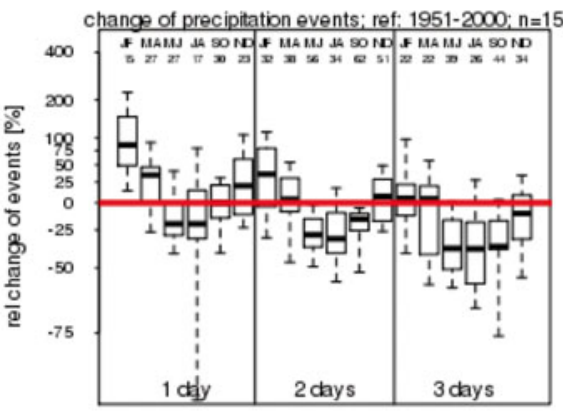

Zermatt precip > 50 mm (2050-99)

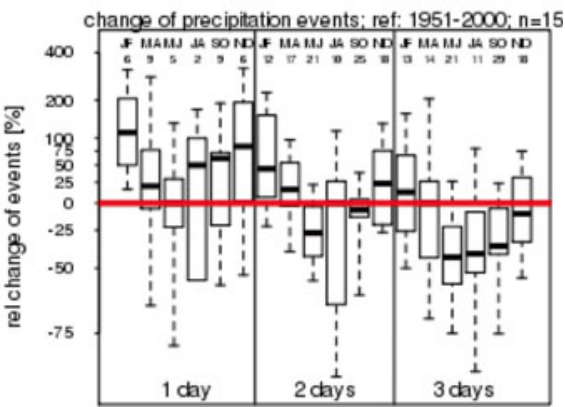


Fig. 3 Changes in liquid precipitation events exceeding the 30 and $50 \mathrm{~mm}$ thresholds at Grächen and Zermatt. The left panels show 2001-2050 projections based on 22 downscaled RCMs, the right panels give 2050-2099 projections obtained from 15 RCMs. Numbers in the top panel show the median number of events of the models in the reference period 1951-2000. Boxplots represent 10th, 25th, 50th, 75th, and 90th percentiles

in the shoulder seasons (mainly in MJ and October). With the projected temperature increase, snowmelt will start earlier in spring and the first persistent snow in autumn will fall later. To account for a possible extension of the debris-flow season, we therefore analyzed changes in "transition months" (i.e., April, MJ, and October) in more detail and by looking at 15-day periods as shown in Table 2. Temperatures above the $5{ }^{\circ} \mathrm{C}$ mean - this value was identified as the lower temperature threshold for past debris-flow events in the study region - proofed to be useful for differentiating liquid from solid precipitation in the source areas of debris flows. Based on the evolution of mean temperatures, an extension of the debris-flow season into late April and late October seems likely, even by 2050, and events in early April and early November are possible by the end of the century.

\subsection{Changing precipitation patterns}

Debris flows are triggered primarily by intensive, but short-lived thunderstorms in summer or by long lasting convective rainfalls in late summer and autumn. Changes in their frequency of occurrence and intensity will ultimately drive the triggering of debris flows as long as temperatures exceed the $5{ }^{\circ} \mathrm{C}$ threshold.

At the annual scale, Fig. S3 illustrates changes in the cycle of daily precipitation, averaged over two months. Comparable patterns of future precipitation changes are expected at both stations. Changes are not significant until 2050, whereas precipitation is projected to increase in ND ( 0.16 and $0.20 \mathrm{~mm} \mathrm{~d}^{-1}$ for Zermatt and Grächen) and JF $\left(0.6\right.$ and $\left.0.18 \mathrm{~mm} \mathrm{~d}^{-1}\right)$ by the end of the $21^{\text {st }}$ century, thereby pointing to more winter precipitation in the region. For the months which are most prone for the occurrence of debris flows, most models project a reduction of mean precipitation totals and in the number of rainy days. In Zermatt, for instance, the median reduction amounts to $-0.47 \mathrm{~mm} \mathrm{~d}^{-1}$ for MJ, $-0.45 \mathrm{~mm} \mathrm{~d}^{-1}$ for JA and $-0.2 \mathrm{~mm} \mathrm{~d}^{-1}$ for SO by 2100 .

In the study region, the release of debris flows is typically driven by short ( $\leq 3$ days) rainfalls, but only very rarely by rain-on-snow events. Antecedent rains are not relevant in the area as the scree slopes of the source areas of debris flows have limited storage capacity. Changes in the number of days with $>10,20,30,40$, and $50 \mathrm{~mm}$ daily liquid precipitation, as well as changes in persisting rainfalls over 2 and $3 \mathrm{~d}$ are presented in Supplementary Table S1. Changes in summer rainfall are clearest in JA, for which the frequency of events exceeding 10 , 20 , and $30 \mathrm{~mm}$ tend to decrease, especially in the case of persistent rainfalls over 2 or $3 \mathrm{~d}$ and more so for the second half of the $21^{\text {st }}$ century. The median decrease is most obvious for 3-day events exceeding 40 or $50 \mathrm{~mm}$, and is in the range of $-50 \%$. On the other hand, very intense, but short-lived (1-day) summer rainfalls exceeding 40 or $50 \mathrm{~mm}$ might still increase, even in summer. At the start (MJ) and the end (SO) of the debris-flow season, the frequency of extreme precipitation events is projected to decrease in Zermatt, whereas a slightly negative or no trend is projected at Grächen. Differences between projections are small for both stations compared to the uncertainties involved, and should not therefore be over-interpreted.

The most interesting and clearest changes are projected for MA and ND. Under current climatic conditions, precipitation likely occurs as snow and the release of debris flows is unusual, but rainfalls could occur at these periods of the year toward the end of the $21^{\text {st }}$ century. A clear increase by at least $30 \%$ is obvious in the frequency of 1-day precipitation 


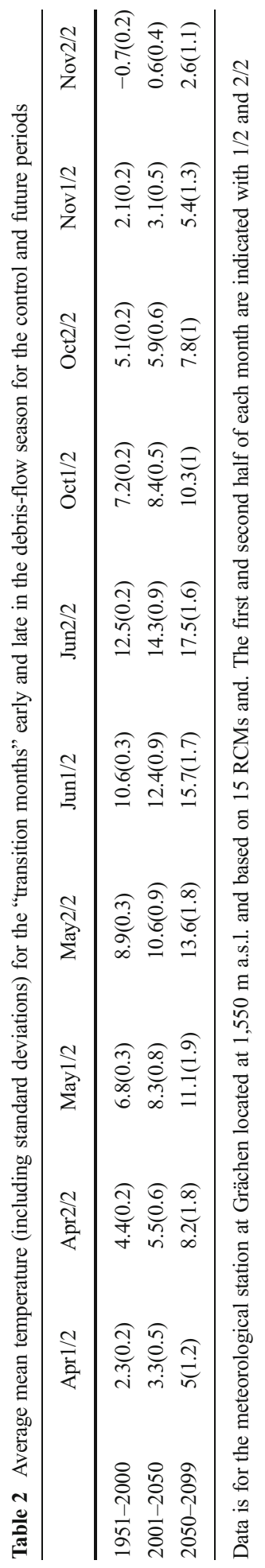


exceeding $20 \mathrm{~mm}$ for Grächen. Modeling results are comparable for Zermatt, but the increase is somewhat less pronounced here.

Supplementary Tables S1 and S2 provide more details on the absolute changes in precipitation events for the periods 2001-2050 and 2050-2099 as compared to 1951-2000. Table S1 illustrates projected changes in liquid and solid precipitation without accounting for temperature, whereas a temperature threshold of $>5{ }^{\circ} \mathrm{C}$ (i.e. a proxy for liquid precipitation at the source areas of debris flows) has been applied in. Changes are not very significant until 2050 for liquid and solid precipitation events with the exception of very extreme ( $>40 \mathrm{~mm} /$ day) 1-day events, which are projected to become more frequent. For the second half of the century models predict a strong increase in the frequency of early (MA) and late (ND) and a decrease in summer (JA) precipitation events, particularly for 2- and 3-day events. If only liquid precipitation is considered (Table S2), an increase is projected in the frequency of heavy precipitation events for spring (MA) and fall (ND). The increase is $\geq 45 \%$ in MA, even for the period 2001-2050. In ND, the increase is $30-44.99 \%$ until 2050 but then increases to $\geq 45 \%$ by 2100 .

\section{Discussion}

Changes in the occurrence and intensity of precipitation events have been analyzed for the stations of Grächen and Zermatt using statistical downscaling techniques. The stations are located in a dry, inneralpine valley of the Swiss Alps where the occurrence of strong precipitation events has been responsible for the triggering of debris flows from periglacial environments (Stoffel et al. 2005a; Schneuwly-Bollschweiler et al. 2013).

At the same time, predicted changes in climatic conditions are also likely to be more pronounced in these high-elevation environments (Beniston 2005; Gobiet et al. 2013) than elsewhere with often drastic and severe consequences on stability and hillslope processes (Stoffel and Huggel 2012, Stoffel et al., subm.). The scarcity of highly-resolved data on past disasters in mountain environments and critically long records of daily temperature and precipitation have repeatedly hampered the analysis of meteorological and hydroclimatic triggers or their impact on the frequency and magnitude of mass movements (Stoffel et al. 2005b; Lopez-Saez et al. 2013).

The datasets analyzed in this contribution are unique as they cover up to 150 years of daily records of temperature and precipitation as well as a comprehensive database on debris flows in eight torrents of the Zermatt valley. In addition, debris flows tend to be released not only by extreme rainfalls, but also by rainfalls $<30 \mathrm{~mm}$ (Schneuwly-Bollschweiler and Stoffel 2012), especially if occurring in MJ and July.

Analysis of temperature and precipitation changes reveals a drying tendency for future summers and more rainfalls during the shoulder seasons. These projections are in concert with observations of Pal et al. (2004) Schmidli and Frei (2005) or Tebaldi et al. (2006) who observed a comparable shift in the seasonality of precipitation in the observational records. A shift can also be observed in the seasonality of debris flows in the Zermatt valley, namely from summer to the shoulder seasons (particularly fall) since 1864 (Schneuwly-Bollschweiler and Stoffel 2012). Despite the general decrease in rainfall volumes in summer, we observe an increase in the occurrence of heavy $(>40 \mathrm{~mm})$ 1-day rainfalls in the region, which corroborates results of previous RCM-based work on extreme precipitation events in Europe (Christensen and Christensen 2003; Frei et al. 2006; Rajczak et al. 2013).

Longer-term changes in mean and extreme temperatures are also expected to impact the stability of hillslopes in the permafrost belt (Harris et al. 2009; Stoffel and Huggel 2012). In the Zermatt valley, sediment sources in this belt are often unlimited and debris flows likely to be 
triggered once that hydroclimatic thresholds are exceeded. Debris-flow volumes tend to increase in summer and fall when the active permafrost layer is thickest and will allow for larger volumes of sediment to be mobilized (Lugon and Stoffel 2010). Conversely, debris-flow volumes have also been shown to depend on the stability of rock glaciers in some catchments (Stoffel and Huggel 2012). Here, debris flows without historic precedents could be released in the future.

The analysis of climatic changes and related possible impacts on the frequency of debris flows does not account for changing sediment sources or mass movements delivering more material to the debris-flow channels, as these processes remain poorly understood. Another source of uncertainty is related to the climate model data and downscaling techniques in general and to the representation of extreme precipitation events in particular.

In this paper, we use the full set of the ENSEMBLES regional climate model (RCM) runs driven by the A1B emission scenario, i.e. 22 (until 2050) and 15 (until 2099). These RCMs are downscaling eight different global circulation models (GCM), of which HadCM3Q0 and ECHAM5 are more often used than others, and will thus influence the climate change signal of the corresponding RCMs (Deque et al. 2007). For summer precipitation, however, the influence of the GCM on the final results is quite low. In the southwestern parts of the Alpine region, GCMs contribute one-third of precipitation change uncertainty, whereas two-thirds stems from the regional downscaling itself (Heinrich and Gobiet 2012). In addition, Heinrich et al. (2013) recently demonstrated that a relatively small number of GCMs, as used in this study, is not expected to cause underestimation of uncertainty.

The horizontal resolution of the RCMs $(25 \mathrm{~km})$ will necessarily lead to a rather imperfect mapping of local physical and meteorological phenomena such as orography, land cover, and/or localized thunderstorms particularly in such complex terrain as the Zermatt valley. Bias correcting and downscaling those models leads to reasonable daily averaged values for meteorological parameters, however, local weather patterns cannot be fully adjusted. The limited resolution of the RCMs therefore has to be seen as an additional source of uncertainty (of unknown relevance). Despite the limitations of bias-corrected RCM data and the uncertainties related to permafrost evolution and sediment delivery to the debris-flow systems in a future climate, several changes may be expected with a reasonable level of certainty in future debris-flow activity in the Zermatt valley.

The predicted warming of mean and extreme air temperatures will very likely lead to a prolongation of the debris-flow season, and in line with what has been observed as a result of climate warming since 1864 (Schneuwly-Bollschweiler and Stoffel 2012). Events might become possible in March, especially in the late $21^{\text {st }}$ century. Such early-season debris flows would remain rather small under current climatic and sediment conditions, but could become larger in the future. They should be seen as critical, even more if rain should fall on previously wetted snow.

A comparable increase can also be expected for ND events. No debris flows have been recorded at this time of the year in the observational records, but events must be expected in a warmer climate, even more so towards the end of the 21 st century. In terms of debris-flow volumes, late-season events are likely to become more critical as larger volumes of ice-free sediment might be available in the source areas of debris flows due to progressive active layer thickening in alpine permafrost regions. The largest events in the observational records have been registered during late-season events (i.e. in September 1920, 1948, 1993) under past climatic conditions (Stoffel et al. 2008), and this trend is likely to continue in a future climate, but at later periods of the year, as rainfalls seem to decline in future summers. Results thus agree with those of Stoffel and Beniston (2006) who anticipate an overall decrease of most intensities for multi-day rainfalls by the end of the century. 


\section{Conclusions}

We conclude that the drier conditions in future summers and the wetting of springs, falls and early winters are likely to have significant impacts on the behavior of debris flows. Stationarity cannot be postulated for debris-flow systems, even less so in high-elevation catchments where the temporal occurrence and spatial distribution of permafrost chiefly controls sediment availability (also over the course of individual years due to changing active layer depths), and the response to climatic changes might be different in the future than today. Nevertheless, based on the current understanding of debris-flow systems and their reaction to rainfall inputs, one might expect only slight changes in the overall frequency of events by the mid- $21^{\text {st }}$ century, but possibly an increase in the overall magnitude of debris flows due to larger amounts of sediment delivered to the channels and an increase in extreme 1-day precipitation events, also during JA and SO. In the second half of the century, however, the overall absolute number of days with conditions favorable for the release of debris flows will likely decrease, in particular in JA. Based on the analysis of the ratio of triggering rainfalls for different thresholds and event durations, the anticipated increase of rainfalls in MA and ND will likely initiate more debris flows during future shoulder seasons. We expect the overall frequency of debris flows to decrease in absolute terms, but the magnitude of events to increase.

The debris-flow channels are crossing linear infrastructure (roads, railway and power lines) and have caused substantial damage in August 1987, September 1993, and October 2000 (Stoffel et al. 2005b). The anticipated destabilization of some rock glaciers (Stoffel and Huggel 2012) and the occurrence of less but larger debris flows will likely lead to events without historical parallels and disasters beyond human experience.

Acknowledgements This work has been undertaken partly in the context of the EU-FP7 project ACQWA (project no. 212250) and Era.Net CICRLE Mountain project ARNICA (10-MCGOT-CIRCLE-2-CVS-116).

\section{References}

BAFU (2006). http://umweltzustand.admin.ch/?reset_session\&initialState=permafrost\&lang=de\#.

Baroni C, Armiraglio S, Gentili R, Carton A (2007) Landform-vegetation units for investigating the dynamics and geomorphologic evolution of alpine composite debris cones (Valle dell'Avio, Adamello Group, Italy). Geomorphology 84:59-79

Beniston M (2005) Mountain climates and climatic change: An overview of processes focusing on the European Alps. Pure and Applied Geophysics 162:1587-1606

Beniston M, Stephenson DB, Christensen OB, Ferro CAT, Frei C, Goyette S, Halsnaes K, Holt T, Jylha K, Koffi B, Palutikof J, Scholl R, Semmler T, Woth K (2007) Future extreme events in European climate: an exploration of regional climate model projections. Climatic Change 81:71-95

Bollschweiler M, Stoffel M (2010) Changes and trends in debris-flow frequency since A.D. 1850 - results from the Swiss Alps. The Holocene 20:907-916

Bollschweiler M, Stoffel M, Schneuwly DM (2008a) Dynamics in debris-flow activity on a forested cone - A case study using different dendroecological approaches. Catena 72:67-78

Bollschweiler M, Stoffel M, Schneuwly DM, Bourqui K (2008b) Traumatic resin ducts in Larix decidua stems impacted by debris flows. Tree Physiology 28:255-263

Borga M, Stoffel M, Marchi L, Marra F, Jakob M (in press) Hydrogeomorphic response to extreme rainfall in headwater systems: flash floods and debris flows. Journal of Hydrology.

Chiarle M, Iannotti S, Mortara G, Deline P (2007) Recent debris flow occurrences associated with glaciers in the Alps. Global Planet Change 56:123-136

Christensen J, Christensen O (2003) Severe summer time flooding in Europe. Nature 421:805-806. doi:10.1038/ $421805 \mathrm{a}$ 
Christensen JH, Carter TR, Rummukainen M, Amanatidis G (2007) Evaluating the performance and utility of regional climate models: the PRUDENCE project. Climatic Change 81:1-6

Crozier MJ (2010) Deciphering the effect of climate change on landslide activity: A review. Geomorphology 124:260-267

Deque M, Rowell DP, Luthi D, Giorgi F, Christensen JH, Rockel B, Jacob D, Kjellstrom E, de Castro M, van den Hurk B (2007) An intercomparison of regional climate simulations for Europe: Assessing uncertainties in model projections. Clim Change 81:53-70

Dobler A, Ahrens B (2008) Precipitation by a regional climate model and bias correction in europe and south asia. Meteorologische Zeitschrift 17(4):499-509

Floris M, D’Alpaos A, Squarzoni C, Genevois R, Marani M (2010) Recent changes in rainfall characteristics and their influence on thresholds for debris flow triggering in the Dolomitic area of Cortina d'Ampezzo, northeastern Italian Alps. Nat Hazards Earth Syst Sci 10:571-580

Frei, C., R. Scholl, S. Fukutome, J. Schmidli, P. L. Vidale (2006), Future change of precipitation extremes in Europe: Intercomparison of scenarios from regional climate models, J. Geophys. Res.-Atmos., 111(D6), doi: $10.1029 / 2005 j \mathrm{j} 005965$.

Gobiet A, Kotlarski S, Beniston M, Heinrich G, Rajczak J, Stoffel M (2013) 21st century climate change in the European Alps - A review. Science of the Total Environment, in press.

Harris C, Arenson LU, Christiansen HH, Etzelmuller B, Frauenfelder R, Gruber S et al (2009) Permafrost and climate in Europe: Monitoring and modelling thermal, geomorphological and geotechnical responses. EarthSci Rev 92:117-71

Heinrich G, Gobiet A (2012) The future of dry and wet spells in Europe: a comprehensive study based on the ENSEMBLES regional climate models. Int J Climatol 32

Heinrich G, Gobiet A, Mendlik T (2013) Extended regional climate model projections for Europe until the midtwentyfirst century: combining ENSEMBLES and CMIP3. Clim Dyn. doi:10.1007/s00382-013-1840-7

IPCC (2012) Managing the risks of extreme events and disasters to advance climate change adaptation. A special report of working group I and II of the Intergovernmental Panel on Climate Change. Cambridge University Press, Cambridge UK

IPCC (2013) Summary for Policymakers. Working Group I Contribution to the IPCC Fifth Assessment Report Climate Change 2013: The Physical Science Basis. Cambridge University Press, Cambridge, UK

Jomelli V, Brunstein D, Grancher D, Pech P (2007) Is the response of hill slope debris flows to recent climate change univocal? A case study in the Massif des Ecrins (French Alps). Clim Change 85:119-137

Jomelli V, Brunstein D, Deque M, Vrac M, Grancher D (2009) Impacts of future climatic change (2070-2099) on the potential occurrence of debris flows: a case study in the Massif des Ecrins (French Alps). Climatic Change 97:171-191

Kääb A (2008) Remote sensing of permafrost-related problems and hazards. Permafr Perigl Proc 19:107-136

Keiler M, Knight J, Harrison S (2010) Climate change and geomorphological hazards in the eastern European Alps. Phil Trans R Soc A 28:2461-2479

Kysely J, Beranova R (2009) Climate-change effects on extreme precipitation in central Europe: uncertainties of scenarios based on regional climate models. Theor Appl Climatol 95:361-374

Lendernik G, Meijgarrd E (2008) Increase in hourly precipitation extremes beyond expectations from temperature changes, Nature Geoscience, 1, doi: 10.1038/ngeo262

Lopez-Saez J, Corona C, Stoffel M, Berger F (2013) Climate change increases frequency of shallow spring landslides in the French Alps. Geology 41:619-622

Lugon R, Stoffel M (2010) Rock-glacier dynamics and magnitude-frequency relations of debris flows in a highelevation watershed: Ritigraben, Swiss Alps. Global Planet Change 73:202-210

Meehl GA, Covey C, Delworth T, Latif M, McAvaney B, Mitchell JFB, Stouffer RJ, Taylor KE (2007) The WCRP CMIP3 multimodel dataset - A new era in climate change research. B Am Meteorol Soc 88:1383

MeteoSwiss (2013) On-line database from MeteoSwiss. http://www.meteoswiss.ch/en/.

Orlowsky B, Seneviratne SI (2012) Global changes in extreme events: regional and seasonal dimension. Clim Change 110:669-696

PAGES 2 k consortium (2013) Continental-scale temperature variability during the past two millennia. Nat Geosci 6:339-346

Pal J, Giorgi F, Bi X (2004) Consistency of recent European summer precipitation trends and extremes with future regional climate projections. Geo Phys Res Lett 31, L19836

Pall P, Allen MR, Stone DA (2007) Testing the Clausius-Clapeyron constraint on changes in extreme precipitation under CO2 warming. Clim Dyn 28(4):351-363

Piani C, Haerter JO, Coppola E (2010) Statistical bias correction for daily precipitation in regional climate models over Europe. Theoretical and Applied Climatology. doi:10.1007/s00704-009-0134-9

Prein AF, Gobiet A, Truhetz H (2011) Analysis of uncertainty in large scale climate change projections over Europe. Meteorol Z 20(4):383-395 
Rajczak J, Pall P, Schär C (2013) Projections of extreme precipitation events in regional climate simulations for Europe and the Alpine Region. Journal of Geophysical Research - Atmospheres 118:1-17

Salzmann N, Noetzli J, Hauck C, Gruber S, Hoelzle M, Haeberli W (2007) Ground surface temperature scenarios in complex high-mountain topography based on regional climate model results. Journal of Geophysical Research-Earth Surface 112:F02S12

Sattler K, Keiler M, Zischg A, Schrott L (2010) On the connection between deris flow activity and permafrost degradation: A case study from the Schnalstal, south Tyrolean Alps, Italy. Permafrost Periglac Process 22: $254-265$

Schmidli J, Frei C (2005) Trends of heavy precipitation and wet and dry spells in Switzerland during the 20th century. Int J Climatol 25(6):753-771

Schmidli J, Schmutz C, Frei C, Wanner H, Schär C (2002) Mesoscale precipitation variability in the region of the European Alps during the 20th century. Int J Climatol 22(9):1049-1074

Schmidli J, Goodess CM, Frei C, Haylock MR, Hundecha Y, Ribalaygua J, Schmith T (2007) Statistical and dynamical downscaling of precipitation: An evaluation and comparison of scenarios for the European Alps. $J$ Geophys Res-Atmos 112

Schneuwly-Bollschweiler M, Stoffel M (2012) Hydrometeorological triggers of periglacial debris flows in the Zermatt valley (Switzerland) since 1864. Journal of Geophysical Research - Earth Surface 117, F02033

Schneuwly-Bollschweiler M, Corona C, Stoffel M (2013) Improvement of dating quality and reduction of noise in tree-ring based debris-flow reconstructions. Quaternary Geochronology,.

Solomon S et al (2007) The Physical Science Basis. Contribution of Working Group I to the Fourth Assessment Report of the Intergovernmental Panel on Climate Change. Cambridge Univ. Press, Cambridge, 996 pp

Stoffel M (2008) Dating past geomorphic processes with tangential rows of traumatic resin ducts. Dendrochronologia 26(1):53-60

Stoffel M (2010) Magnitude-frequency relationships of debris flows - A case study based on field surveys and tree-ring records. Geomorphology 116:67-76

Stoffel M, Beniston M (2006) On the incidence of debris flows from the early Little Ice Age to a future greenhouse climate: A case study from the Swiss Alps. Geophys Res Letter 33, L16404

Stoffel M, Huggel C (2012) Effects of climate change on mass movements in mountain environments. Progress in Physical Geography 36:421-439

Stoffel M, Lièvre I, Monbaron M, Perret S (2005a) Seasonal timing of rockfall activity on a forested slope at Täschgufer (Swiss Alps) - A dendrochronological approach. Zeitschrift für Geomorphologie 49:89-106

Stoffel M, Lièvre I, Conus D, Grichting MA, Raetzo H, Gärtner HW, Monbaron M (2005b) 400 years of debris flow activity and triggering weather conditions: Ritigraben VS, Switzerland. Arctic, Antarctic and Alpine Research 37(3):387-395

Stoffel M, Conus D, Grichting MA, Lièvre I, Maitre G (2008) Unraveling the patterns of late Holocene debrisflow activity on a cone in the Swiss Alps: Chronology, environment and implications for the future. Global and Planetary Change 60:222-234

Stoffel M, Bollschweiler M, Beniston M (2011) Rainfall characteristics for periglacial debris flows in the Swiss Alps: past incidences - potential future evolutions. Climatic Change 105:263-280

Tebaldi C, Hayhoe K, Arblaster J, Meehl GA (2006) Going to the extremes: An intercomparison of modelsimulated historical and future changes in extreme events. Climatic Change 79(3-4):185-211

Themeß1 MJ, Gobiet A, Leuprecht A (2011) Empirical-statistical downscaling and error correction of daily precipitation from regional climate models. International Journal of Climatology 31(10):1530-1544

Themeß1 MJ, Gobiet A, Heinrich G (2012) Empirical-statistical downscaling and error correction of regional climate models and its impact on the climate change signal. Climatic Change 112(2):449-468

Widmann M, Schär C (1997) A principal component and long-term trend analysis of daily precipitation in Switzerland. Int J Climatol 17(12):1333-1356

Wilcke R, Mendlik T, Gobiet A (2013) Multi-variable error correction of regional climate models. Clim Change 120(4):871-887 